\title{
Strategi Peningkatan Kualitas Pelayanan Publik pada Dinas Penanaman Modal Dan Pelayanan Terpadu Satu Pintu Kabupaten Melawi
}

\author{
Rikka Septiandini ${ }^{1}$ \\ 1. Pemda Kabupaten Melawi
}

Korespondensi Penulis : rikkaseptiandini@gmail.com

\begin{abstract}
This research aim is to analyze the quality of public service in Investment and one-stop service Office (DPMPTSP) of the Melawi Regency. DPMPTSP is one of the government institutions which is categorized on the red zone in public service by the Indonesia Ombudsman of West Kalimantan Province. The research method uses a qualitative method. It is used the service dimension theory then analyzed with SWOT analysis and measured against the theory of service quality improvement strategies. The results of the research show 4 outlines of strategies that can be used by using strengths to take advantage of opportunities, take advantage of opportunities to overcome weaknesses, use strengths to avoid threats, and minimize weaknesses to avoid threats. The resulting strategy is very useful for improving the quality of service delivery in DPMPTSP Melawi Regency.
\end{abstract}

Key words: The Service Strategy, Strengths, Weaknesses, Opportunities, Threats

\section{PENDAHULUAN}

Dalam rangka meningkatkan pelayanan kepada masyarakat berdasarkan Peraturan Menteri Dalam Negeri Nomor 20 Tahun 2008 tentang Pedoman Organisasi dan Tata Kerja
Unit Pelayanan Terpadu di Daerah, maka dibentuklah Dinas Penanaman Modal dan Pelayanan Terpadu Satu Pintu (DPMPTSP) di Kabupaten Melawi berdasarkan Peraturan Daerah Kabupaten Melawi Nomor 10 Tahun 
2016 tentang Pembentukan dan berdampak pada hasil penilaian

Susunan Perangkat Daerah Kabupaten

Melawi,sertaPeraturanBupatiMelawi

Nomor 55 Tahun 2016 tentang

Kedudukan, Susunan Organisasi,

Tugas Pokok dan Fungsi serta Tata Kerja DPMPTSP KabupatenMelawi.

Pelayanan publik merupakan suatu hal yang penting dan menjadi kebutuhan masyarakat tentunya menjadi perhatian instansi penyelenggara pelayanan yang secara langsung diberikan kepada masyarakat. Khususnya DPMPTSP Kabupaten Melawi harus terus berupaya untuk memberikan pelayanan publik yangmemenuhi harapan masyarakat, dapat memberikan tanggapan terhadap keluhan pelanggan, dapat memanfaatkan teknologi dengan maksimal dalam memberikan pelayanan yang cepat, tepat dan akurat, serta dapat menjaga kualitas dan menerapkan standar pelayanan yang tepat sesuai dengan moto dan janji layanan yang telah ditetapkan sehingga akan memunculkan pandangan positif dari masyarakat terhadap layanan publik yang diberikan maupun bagi lembaga penilai pelayanan publik yang kepatuhan yang baik pada DPMPTSP Kabupaten Melawi sebagai salah satu instansi penyelenggara pelayanan publik.

Pengertian pelayanan (service) menurut American Marketing Association seperti dikutipoleh Cowell 1988 (dalam Hardiyansyah 2018:13) bahwa pelayanan pada dasarnya merupakan kegiatan atau manfaat yang ditawarkan oleh suatu pihak kepada pihak lain dan pada hakekatnya tidak berwujud serta tidak menghasilkan suatu kepemilikan sesuatu, proses produksinya mungkin juga tidak dikaitkan dengan suatu produk fisik. Sedangkan menurut Lovelock 2011 (dalam Hardiyansyah 2018:14) "service adalah produk yang tidak berwujud, berlangsung sebentar dan dirasakan atau dialami."Artinya service merupakan produk yang tidak ada wujud atau bentuknya sehingga tidak ada bentuk yang dapat dimiliki, dan berlangsung sesaat atau tidak tahan lama, tetapi dialami dan dapat dirasakan oleh penerimalayanan.

Namun demikian berdasarkan Hasil Penilaian Kepatuhan KabupatenMelawi terhadap Undang- 
Undang Nomor 25 Tahun 2009 tetang Pelayanan Publik Tahun 2018 oleh Ombudsman RI yang merupakan lembaga negara yang mempunyai kewenangan mengawasi penyelenggaraan pelayanan publik dengan menggunakan Aplikasi Sistem Informasi Kepatuhan Ombudsman RI memperlihatkan bahwa terdapat 55 (Lima Puluh Lima) Produk Layanan pada 11 (sebelas) Dinas dengan nilai rata-rata keseluruhan 29,73 yang menunjukkan keberadaan pada Zona Merah dengan tingkat kepatuhan rendah. Dari 55 (Lima Puluh Lima ).

Berdasarkan Keputusan Menteri Pemberdayaan Aparatur negara Nomor 63 Tahun 2003, definisi dari pelayanan umum adalah:“ segala bentuk pelayanan yang dilaksanakan oleh instansi pemerintahan di pusat, di daerah, dan di lingkungan Badan Usaha Milik Negara atau Badan Usaha Milik Daerah dalam bentuk barang danataujasa,baikdalamrangkaupayape menuhankebutuhanmasyarakatmaupun dalam rangka pelaksanaan ketentuan peraturan perundang-undangan”. Sedangkan menurut BabI Pasall Ayat1 Undang-Undang No.25/2009 yang dimaksud dengan pelayanan public adalah kegiatan atau rangkaian kegiatan dalam rangka pemenuhan kebutuhan pelayanan sesuai dengan peraturan perundang-undangan bagi setiap warga Negara dan penduduk atas barang, jasa dan/ atau pelayanan administrative yang disediakan oleh penyelenggaraan pelayananpublik.

Peneliti mengidentifikasi masalah yang akan diteliti berkaitan dengan latar belakang masalah yang ada, antara lain sebagai berikut :

1. Kondisi sumberdaya aparatur dengan keterbatasan sarana prasarana serta rendahnya inisiatif dan skilldalam memaksimalkan pemanfaatan teknologi sehingga mempengaruhi kualitas kinerja pelayanan.

2. Rendahnya pemahaman masyarakat mengenai pelayanan dan stigma negatif yang beredar dimasyarakat bahwa perizinan berbelit-belit, lama, dan mahal.

3. Masyarakat yang enggan mengurus izin sendiri dan lebih mempercayakan kepada pihak ke-3 ataucalo.

Berdasarkan uraian pada latar belakang maka fokus dalam enelitianini yaitu strategi yang akan 
ditawarkan dalam peningkatan kualitas pelayanan publik pada Dinas Penanaman Modal dan Pelayanan Terpadu Satu Pintu (DPMPTSP) Kabupaten Melawi berdasarkan hasil pengukuran terhadap indikator pelayanan publik yang dianalisis menggunakan analisis SWOT (Strenght, Weaknesses, Opportunities, and Threats) guna memperoleh strategi penyelesaian masalah yang diuji menggunakan indikator strategi peningkatan kualitas pelayanan yang akan dilaksanakan pada Dinas Penanaman Modal dan Pelayanan Terpadu Satu Pintu(DPMPTSP) Kabupaten Melawi sebagai salah satu instansi penyelenggara pelayanan publik.

\section{METODE PENELITIAN}

Jenis penelitian yang digunakan dalam penelitian ini adalah jenis penelitian deskriptif dengan pendekatan kualitatif. Dimana dalam penelitian ini bertujuan untuk mengambarkan situasi pelayanan pada DPMPTSP Kabupaten Melawi, bagaimana sikap, perilaku, pandangan, fenomena dan proses yang berlangsung dilokasi penelitian. Serta merekomendasikan strategi yang dapat digunakan untuk meningkatkan kualitas pelayanan publik. Pengumpulan data dengan suatu latar alamiah, dengan menggunakan metode alamiah dan dilakukan oleh peneliti yang tertarik secara alamiah.

Dalam penelitian kualitatif ini peneliti memanfaatkan wawancara terbuka untuk menelaah dan memahami sikap, pandangan, perasaan dan perilaku individu terkait pelayanan di DPMPTSP Kabupaten Melawi. Dengan demikian, pendekatan kualitatif dapat disimpulkan sebagai penelitian yang menggunakan pendekatan alamiah untuk mengambarkan realitas yang kompleks. Dalam penelitian ini masalah yang diteliti masih bersifat sementara dan berkembang setelah peneliti berada dilapangan. Peneitian kualitatif menghasilkan prosedur analisis yang tidak menggunkan prosedur analisis statistik atau cara kuantifikasi lainnya, yang mana penelitian ini mendasar pada upaya membangun pandangan mereka yang diteliti dengan rinci dibentuk dengan kata-kata.

\section{HASIL DAN PEMBAHASAN}

Merujuk pada data yang telah 
dihimpun, peneliti menetapkan 5 (lima) indicator yang akan dijelaskan sebagai berikut.

\section{Dimensi Tangible (Berwujud)}

Hasil pengukuran terhadap kualitas pelayanan berdasarkan 5 (lima) indikator tersebut diuraikan sebagai berikut:

Untuk mengukur dimensi tangible, peneliti melihat dari dua perspektif yakni aktor sebagai penyedia layanan dan masyarakat selaku objek layanan..

Berdasarkan hasil wawancara dan observasi yang telah dilakukan oleh peneliti, secara umum dimensi tangible dikatakan telah terlaksana pada DPMPTSP Kabupaten Melawi. Hal ini terlihat dari tercapainya 6 (enam) indikator dimensi tangible yakni tersedianya petugas pelayanan dalam jumlah yang cukup, berpenampilan baik serta dilengkapi dengan seragam khusus dan tanda pengenal. Tersedianya tempat pelayanan yang memadai dilengkapi dengan loket/meja pelayanan, ruang tunggu layanan, ruang laktasi dan fasilitas kursi roda bagi penyandangdisabilitas.

Hasil wawancara menunjukkan bahwa jumlah aparatur penyelenggara layanan ada 9 (sembilan) orang sesuai tugas pokok dan fungsinya masingmasing. Dikatakan bahwa para petugas baik front office maupun back office dinilai cukup cakap dan bertanggungjawab dalam melaksanakan tugasnya.

\section{Dimensi Reliability (Kehandalan)}

Dari hasil wawancara tersebut diketahui bahwa aparatur pelaksan atelah memahami tugas pokok dan fungsinya serta menjalankan tugas penuh tanggungjawab meskipun ketelitian dalam hal memeriksa berkas kelengkapan pengurusan izin masih harus ditingkatkan. Hal yang menjadi kendala adalah kurangnya kemampuan aparatur secara teknis.

Penyelenggaraan pelayanan publik terbaru menggunakan OSS menuntut pemahaman dalam hal pengoperasian sistem aplikasi pelayanan yang telah disediakan secara nasional. Aparatur pelaksana pada DPMPTSP Kabupaten melawi tidak memiliki latar belakang pendidikan yang spesifik terkait pengoperasian komputer jaringan maupun sistem. Hal ini terjadi karna kurangnya sumber daya manusia aparatur sehingga harus memanfaatkan apa SDM yang telah 
ada. Ini mengapa kemampuan aparatur pelaksana masih terbatas terutama saat terjadi hambatan seperti sistem eror atau kesalahan dalam hal input data, maka perbaikan sistem juga memelukan waktu lama yang mana berpengaruh terhadap kualitas waktu pelayanan.

Berdasarkan hal tersebut, DPMPTSP berharap pemerintah secara umum mau mendukung usaha dalam meningkatkan kualitas SDM melalui keikutsertaan aparatur pelaksana dalam pelatihan dan bimbingan teknis mengenai penyelenggaraan pelayanan dan OSS sembari menunggu tersedianya tenaga teknis khusus melalui pembukaan CPNS.

\section{Dimensi Responsiveness}

\section{(Ketanggapan)}

Berdasarkan hasil wawancara terhadap aparatur pelaksana, dikatakan bahwa pihak aparatur terus berusaha untuk meningkatkan kualitas pelayanan meski pada kenyataannya masih saja terdapat rapor merah dari ombudsman namun hal tersebut tidak menjadikan pihak DPMPTSP Kabupaten Melawi untuk tidak memberikan pelayanan terbaik kepada masyarakat. Standar prosedur telah tertera jelas pada SOP yang ditempel pada papan informasi DPMPTSP Kabupaten Melawi, mengenai informasi dan hal lain yang ingin diketahui oleh masyarakat dapat dilihat baik pada papan informasi maupun melalui website DPMPTSP Kabupaten Melawi. Apabila masyarakat merasa kurang puas dengan pelayanan yang diberikan, tersedia pula kotak pengaduan yang akan ditanggapi maksimal 3x24 jam.

Masyarakat merasa cukup puas dengan pelayanan yang ada, kendala yang ditemui umumnya masalah waktu yang juga telah dikonfirmasi oleh petugas dimana mereka terkadang terkendali masalah jaringan internet sehingga kesulitan untuk menjalankansistemyangberakibatpada keterlambatanwaktupelayanan,menge nai hal pelayanan jemput bola juga telah di konfirmasi oleh Kepala DPMPTSP Kabupaten Melawi bahwau ntuk saat ini mereka belum mampu mewujudkan hal tersebut karna kurangnya SDM, sarana prasarana, serta keterbatasan anggaran.

Berdasarkan hasil wawancara dan observasi terhadap indikator 
dimensi responsiveness, dapat disimpulkan bahwa DPMPTSP Kabupaten Melawi belum sepenuhnya mampu memenuhi indikator ini dikarenakan hambatan terkait waktu pelayanan, koordinasi dengan pihak OPD dan sistem jaringan belum sempurna.

\section{Dimensi Assurance(Jaminan)}

Berdasarkan hasil penelitian yang telah dilakukan, peneliti melihat bahwa DPMPTSP Kabupaten Melawi telah mampu memenuhi indikator dimensi assurance. Namun rendahnya nilai kepatuhan standar pelayanan publik pada DPMPTSP Kabupaten Melawi berdasarkan penilaian ombudsman, menggeliti peneliti untuk melakukan penelitian lebih mandalam terkait hal ini, melihat kenyataan lapangan semua tampak berjalan sesuai aturan, namun ternyata terdapat budaya masyarakat sendiri yang justru memunculkan stigma negatif terkait pelayanan.

Terkait masyarakat yang lebih memilih untuk menggunakan jasa pihak ketiga atau "Calo" hal ini tentunya harus ditertibkan harus ada sanksi yang tegas bagipara Calo dan apabila ada oknu maparatur yang mendukungataubekerjasama dengan Calo tersebut tentu harus ikut ditindak dengan tegas. Dengan adanya sanksi yang tegas seperti diberlakukan denda atau bahkan tidak keluarnya izin tentu akan memberi efek jera yang diharapkan dapat mengurangi hingga menghilangkan penggunaan jasa pihak ketiga atauCalo.

\section{Dimensi Emphaty(empati)}

Empati merupakan cara atau pendekatan yang dilakukan oleh penyedia layanan terhadap pelanggan, pelanggan hendaknya diperlakukan secara baik dan adil tanpa ada pembedaan sehingga setiap pelanggan merasa dihargai. Penliaian atas dimensi ini dilakukan dengan memperhatikan sikap aparatur terhadap masyarakat yani bagaimana aparatur mampu memperlakukan masyarakat dengan pendekatan yang baik sehingga a nggapan dan stigma negative tentang pelayanan izin dapat dihilangkan.

Berdasarkan hasil wawancara, 
observasi dan studi kepustakaan, maka dapat dikatakan bahwa DPMPTSP Kabupaten Melawi telah berusaha memenuhi dimensi emphaty dalam pelenyelenggaraan pelayanan meski dalam prakteknya human eror masih tidak dapat dihindari secarap penuh, seperti keterlambatan petugas dan kesalahan-kesalahan sikap yang tidakdisengaja.

Setelah dilakukan pengukuran terhadap 5 (lima) dimensi pelayanan menggunakan indikator-indikator yang ditetapkan berdasarkan teori Zeithaml (dalam Hardiyansyah, 2018) diperoleh hasil penelitian sebagai berikut:

Dari 5 (lima) dimensi pelayanan, DPMPTSP Kabupaten Melawi telah memenuhi $70 \%$ indikator. Kekurangan terdapat pada dimensi tangible yaitu ketersediaan sarana dan prasarana yang belum mampu mendukung pelayanan optimal karena internet yang lambat dan sistem aplikasi pelayanan terkadang eror, dimensi reliability yakni faktor human eror, dimensi responsiveness terkait waktu pelayanan, koordinasi antar OPD, dan sistem jaringan yang belum sempurna, dimensi assurance yakni kurangnya keterlibatan masyarakat sehingga muncul stigma negative terkait pelayanan, dan dimensi emphaty yakni keterlambatan petugas yang bersifat kondisional bukan karena hal yang disengaja. Namun secara umum seluruh indikator telah terpenuhi dengan cukupbaik.

\section{Analisis SWOT dalam Penetapan Strategi \\ Setelah mengelompokkan faktor} internal dan eksternal yang didapat dari hasil pengukuran indicator 5 dimensi pelayanan terhadap penyelenggaraan layanan di DPMPTSP Kabupaten Melawi, selanjutnya peneliti membagi hal tersebut menjadi kekuatan, kelemahan, peluang, dan ancaman untuk melanjutkan analisa menggunakan matrix SWOT yang menggambarkan bagaimana manajemen dapat mencocokkan peluang-peluang dan ancaman-ancaman eksternal yang dihadapi suatu perusahaan tertentu dengan kekuatan dan kelemahan internalnya untuk menghasilkan empat rangkaian alternatif strategis (Hunger \& Wheelen, 1996).

Analisis SWOT yang telah dilakukan oleh peneliti menghasilkan strategi peningkatan kualitas pelayanan 
yang menggunakan kekuatan untuk memanfaatkan peluang (SO), memanfaatkan peluang mengatasi kelemahan (WO), menggunakan kekuatan untuk menghindari ancaman (ST), dan meminimalkan kelemahan serta menghindari ancaman(WT).

Strategi SO yang dihasilkan adalah Mewujudkan komitmen aparatur untuk membuat program kegiatan menggunakan anggaran yang tersedia guna merangkul masyarakat agar turut serta dalam usaha peningkatan kualitas pelayanan dengan memanfaatkan perkembangan teknologi (OSS). Hal ini dipilih karena kekuatan yang dimuliki oleh DPMPTSP adalah komitmen para aparatur pelaksana untuk melaksanakan fungsi pelayanan dan peluang yang ada saat ini adalah adanya teknologi pelayanan terbaru yakni OSS sehingga hal ini dapat di manfaatkan sebagai strategi untuk meningkatkan kualitas penyelenggaraan pelayanan. Strategi WO yang dihasilkan adalah memanfaatkan teknologi semaksimal mungkin dalam hal pengurusan perizinan (OSS), sosialisasi mengenai pelayanan perizinan terkait prosedur, syarat, waktu, dan biaya melalui media sosial (facebook, instagram, youtube, website dll) dan koordinasi koordinasi antar instansi (melalui aplikasi zoom, whatsapp, skype, dll) hal ini dikarenakan kelemahan internal adalah kurangnya anggaran sehingga sosialisasi secara offline sulit terlaksana namun peluang terkait sosialisasi melalui media sangat besar sehingga hal ini dapat dimanfaatkan guna mengatasi kelemahan yang ada.

Strategi ST yang dihasilkan adalah dengan cara menunjukkan komitmen kerja yang tinggi, konsistensi, dan inovasi petugas agar dapat menghilangkan stigma negatif, sistem eror, koneksi internet yang lambat yang tumbuh dimasyarakat hal ini dikarenakan komitmen aparatur adalah kekuatan internal yang dimiliki dan stigma negatif, sistem eror, koneksi internet yang lambat merupakan salah satu ancaman terhadap kualitas penyelenggaraan pelayanan. Strategi WT yang dihasilkan adalah melakukan sistem back up data, meminimalisir human eror, dan fokus pada penyelenggaraan yang telah ada dari pada memaksa 
untuk mengadopsi sistem baru yang belum mampu diterapkan karena hambatan yang bersifat teknis dan tidak tersedianya sarana dan prasarana, dengan demikian DPMPTSP Kabupaten Melawi dapat meminimalkan kelemahan guna menghindariancaman.

\section{Strategi KualitasPelayanan}

Setelah melakukan analisis SWOT peneliti merumuskan strategi yang kemudian akan dikaji kembali menggunakan indikator teori strategi peningkatan kualitas pelayanan menurut De Vreye (dalam Hardiyansyah 2018:69) yakni : Selfesteem (harga diri/ kualitasdiri). Exeed expectation

(memenuhiharapan). Recovery (pembenahan). Vision (pandangan kedepan) Improve (perbaikan). Care (perhatian).

Empower

(pemberdayaan)

\section{Self-esteem diri/kualitasdiri)}

Indikator ini melihat bahwa peningkatan kualitas pelayanan dapat dilakukan dengan menempatkan seseorang sesuai dengan keahliannya dan menetapkan tugas pelayanan yang berorientasi masa depan. DPMPTSP Kabupaten Melawi berusaha melaksanakan ini melalui penempatan yang tepat bagi para petugas pelayanan (the right man in the right place) namun hambatan masih ditemukan terkait latar belakang pendidikan petugas layanan dan operator system yang masih beragam dan belum spesifik serta terbatasnya anggaran untuk mengikutsertakan para aparatur dalam pelatihan dan bimbingan teknis pelayanan dan pengoperasian sistem. Meski demikian, Kepala DPMPTSP Kabupaten Melawi menyatakan bahwa para aparatur pelaksana telah dibekali dengan pelatihan in job training dan memiliki sertifikat dari Badan Koordinasi PenenamanModal.

Dalam usaha meningkatkan kualitas pelayanan, aparatur pelaksana jangan hanya terpaku pada keterbatasan fasilitas namun juga harus mampumemanfaatkan teknologi semaksimal mungkin guna menutupi kekurangan yang ada. Strategiyang dapat dilakukan terkait indikator ini adalah Memanfaatkan teknologi semaksimal mungkin dalam hal pengurusan perizinan (OSS), sosialisasi mengenai pelayanan 
perizinan terkait prosedur, syarat, waktu, dan biaya melalui media sosial(facebook, instagram, youtube, website dll) dan koordinasi antar instansi (melalui aplikasi zoom, whatsapp, skype, dll) (StrategiWO).

\section{Exceed ecpactation ( pemenuhan harapan)}

Penyelenggara pelayanan harus mampu memahami keinginan masyarakat dan berusaha agar layanan yang diberikan sesuai standar sehingga harapan masyarakat terhadap penyelenggaraan pelayanan dapat terpenuhi. Dimensi emphaty memiliki pengaruh yang besar terhadap indikator ini. pelaksana dituntut untukmampubersikapbaik,ramah,sopan ,dancermatsertamenguasaistandardan SOP pelayanan. DPMPTSP Kabupaten melawi telah mampu memenuhi dimensi emphaty hanya saja faktor human eror masih terjadi seperti sikap yang tidak disengaja, kurang teliti dalam pemeriksaan berkas, dan lain sebagainya, pada umumnya bersifat kondisional dan tidak fatal. Masyarakat secara garis besar menyatakan puas akan pelayanan yang terselenggara di DPMPTSP Kabupaten Melawi meskipun masih kadang terjadi human eror yang dilakukan olehpetugas.

Strategi peningkatan kualitas penyelenggaraan pelayan pada indikator ini dapat dilakukan dengan menunjukkan komitmen yang tinggi dalam penyelenggaraan pelayanan guna menghilangkan stigma negatif tentang perizinan, konsistensi petugas pelayanan dalam menjalankan tupoksi baik melalui sistem maupunmanual (StrategiST) dan meminimalisir faktor human eror guna mencegah kalalaian dalam pelayanan (StrategiWT).

\section{Recovery (Penyembuhan)}

Setiap instansi penyelenggara layanan tentu harus melakukan pembenahan terhadap hasil kerja yang telah dilaksanakan melalui evaluasi maupun berdasarkan saran, kritik dan keluhan pelanggan. Hal ini penting agar kesalahan dan kekurangan yang ada dapat diperbaiki sehingga image dan kualitas penyelenggaran pelayanan meningkat. Indikator ini erat kaitannya dengan dimensi responsiveness. Berdasarkan hasil pengukuran yang telah dilakukan oleh peneliti, DPMPTSP

KabupatenMelawibelumsepenuhn 
yamampumemenuhiindikatorinidikare nakan hambatan terkait waktu pelayanan, koordinasi dengan pihak OPD dan sistem jaringan belum sempurna. Berdasarkan hasil tersebut, pembenahan demi pembenahan masih terus dilakukan hingga saat ini, pengaduan, kritik dan saran selalu berusaha untuk ditanggapi oleh aparatur dengan jangka waktu maksimal 3x24jam.

Strategi guna mengatasi hal tersebut diatas dan meningkatkan kualitas penyelenggaraan pelayanan adalah dengan cara aktif meminta saran masukan dari masyarakat terkait kinerja dan kualitas pelayanan sehingga dapat dilakukan pembenahan terhadap kesalahan yang ada (StrategiSO) dan melaksanakan evaluasi secara berkala terhadap kinerja dan kualitas pelayanan berdasarkan pengaduan masyarakat dan produk layanan terbaru (Strategi WO). Pembenahan harus terus dilakukan meskipun peningkatan kualitas penyelenggaraan pelayanan telah tercapai demi memberikan pelayanan optimal kepadamasyarakat.

Vision (Pandangan Ke depan)
Penyelenggara

pelayanan hendaknya mampu memprediksi kondisi masyarakat dimasa yang akan datang terkait kebutuhan produk perizinan. Adopsi dan adaptasi sistem perizinan dalam rangka mencari bentuk terbaik menjadi hal yang lumrah dilakukan seperti adanya system perizinan terpadu satu atap, pelayanan terpadu satu pintu, hingga pada mall pelayanan public merupakan adopsi dan adaptasi serta inovasi dalam bidang perizinan guna mengakomodir kebutuhan perizinan saat ini dan masa yang akan datang.

DPMPTSP Kabupaten Melawi terus berusaha memberikan pelayanan terbaik dengan mengadopsi dan memanfaatkan kemajuan teknologi guna menyusun perencanaan tentang program kegiatan yang diharapkan mampu mengakomodir kebutuhan masyarakat terkait produk perizinan, namun pada implementasinya masih ditemukan hambatan yakni teknologi baru yang belum mampu diterapkan karena keterbatasan anggaran dan SDM terampil serta belum tersedianya layanan jemput bola atau drive-thru dikarenakan kurangnya SDM apatur, fasilitas sarana 
danprasarana.

Strategi untuk mengatasi hal tersebut dan meningkatkan kualitas penyelenggaraan yakni aparatur pelaksana diharapkan dapat fokus terhadap penyelenggaraan pelayanan yang telah ada sebaik mungkin dari pada memaksa untuk mengadopsi sistem baru yang belum mampu dijalankan dikarenakan hambatan yang bersifat teknis dan tidak tersedianya sarana prasarana (StrategiWT) dan Konsistensi perugas dalam menjalankan tupoksi baik melalui sistem maupun manual (Strategi ST). Dengan demikian pelayanan yang telah terselenggara dapat terlaksana semaksimal mungkin sembari menunggu instansi siap secara sumber daya baik sumber daya manusia terkait ketersediaan tenaga terampil maupun finansial berupa anggaran untuk menerapkan dan mengimplementasikan teknologi penyelenggaraan pelayananterbaru.

\section{Improvement (Perbaikan)}

Implementasi pelayanan publik tidak terlepas dari berbagai bentuk masalah, baik yang bersifat teknis maupun sumber daya. Oleh karenanya perbaikan harus terus dilakukan agar kualitas pelayanann semakin baik. Perbaikan hendaknya dilakukan oleh seluruh aparatur pelaksana secara bersama-sama melalui evaluasi secara berjenjang untuk selanjutnya ditemukan solusi atas masalah yang ada. DPMPTSP Kabupaten Melawi terus berusaha memberikan yang terbaik dalam hal pelayanan perizinan, guna mewujudkan hal tersebut selain melaksanakan penyelenggaraan pelayanan, juga disusun programm kegiatan yang dinilai dapat menunjang dan memaksimalkan penyelenggaraan pelayanan.

Penyelenggaraan pelayanan yang baik tidak dapat dilakukan oleh pihak aparatur pelaksana tanpa bantuan partisipasi aktif dari masyarakat. Menyadari hal tersebut DPMPTSP Kabupaten Melawi berusaha melakukan perbaikan terhadap program kegiatan yang ada, dengan cara melibatkan masyarakat untuk ikut berpartisipasi guna meningkatkan kualitas pelayanan. Strategi yang disusun terkait hal ini adalah mewujudkan komitmen aparatur untuk membuat program kegiatan menggunakan anggaran yang tersedia guna merangkul masyarakat agar turut 
serta dalam usaha peningkatan kualitas pelayanan dengan memanfaatkan perkembangan teknologi (OSS) (Strategi SO). Melalui OSS masyarakat dapat ikut berperan aktif dalam usaha meningkatkan kualitaspelayanan.

\section{Care (Perhatian)}

Perhatian merupakan unsur penting yang harus ada dalam penyelenggaraan pelayanan dimana pelayanan yang ada diharap mampu memecahkan masalah dan menjadi solusi bagi masyarakat sebagai objek pelayanan. Terkait pelayanan perizinan, dengan adanya perizinan yang jelas maka masyarakat memiliki kekuatan hukum terhadap hal yang mereka miliki atau mereka lakukan, dengan demikian negara menjamin keamanan dan hak mayarakat melalui dokumen perizinan yang telah dikeluarkan, hal tersebut merupakan salah satu bentuk perhatian terhadap masyarakat.

Dalam menyelenggarakan pelayanan, DPMPTSP Kabupaten Melawi berusaha menjaga kualitas dan menerapkan standar pelayanan yang tepat guna memuaskan masyarakat. Hal ini tampak pada tersedianya fasilitas yang memadai seperti ruang tunggu, ruang laktasi, kursi roda, dan meja pelayanan, adanya SOP yang jelas, tersedianya papan informasi dan website untuk memudahkan masyarakat memperoleh informasi valid terkait pelayanan yang diselenggarakan. Semua hal tersebut merupakan bentuk perhatian pemerintah terhadap masyarakat meskipun pada implementasinya masih terdapat kekurangan seperti jaringan internet yang belum stabil dan kurangnya koordinasi antar instansi sehingga berdampak pada keterlambatan pelayanan maupun sosialisi yang masih belum dapat dilakukan secara maksimal dikarenakan keterbatasan anggaran yang berdampak pada munculnya stigma negatif bahwa pelayanan ini berbelit-belit, lama, dan mahal

Guna mengatasi masalah tersebut dan untuk meningkatkan kualitas penyelenggaraan layanan, strategi yang dapat dilakukan adalah dengan memanfaatkan teknologi semaksimal mungkin, melakukan sosialisasi mengenai pelayanan perizinan terkait prosedur, syarat, waktu, dan biaya 
melalui media sosial (facebook, instagram,youtube,website dll) dan koordinasi koordinasi antarinstansi (melalui aplikasi zoom, whatsapp, skype, dll) (StrategiWO).

\section{Empowerment (Pemberdayaan)}

Indikator ini terkait pemberdayaan terhadap aparatur dengan belajar dari pengalaman dan memberikan pendidikan dan pelatihan bagi aparatur. Hal ini penting karena aparatur yang berkompeten merupakan salah satu faktor pendukung meningkatnya kualitas pelayanan. DPMPTSP Kabuapaten Melawi telah membekali para aparatur pelaksananya dengan in job training sehingga diharapkan aparatur mampu melaksanakan tupoksi sebaik-baiknya. Selain itu meraka yang bertugas juga telah memiliki sertifikat dari badan koordinasi penanaman modal yang berarti bahwa aparatur memiliki skill terkait penyelenggaraan pelayanan. Pada implementasinya hal tersebu tbelum cukup, selain in job training dan sertifikat dari badan koordinasi penanaman modal, aparatur juga hendaknya mengikut pelatihan dan bimbingan teknis lainnya terkait pelayanan dan pengoperasian sistem.
Namun keterbatasan anggaran untuk mengikutsertakan aparatur pada pelatihan dan bimbingan teknis terkait pelayanan masih menjadi hambatan yang harus dihadapi hingga saat penelitian ini dilakukan.

Guna mengatasi masalah tersebut agar kualitas pelayanan dapat terus ditingkatkanmakastrategiiyangdapatdil akukanolehaparaturadalahmempelajari secara manual melalui internet hal-hal terkait penyelenggaraan pelayanan (misalnya melalui video di youtube, materi-materi yang ada di internet dan lain sebagainya) (Strategi ST). Keterbatasan yang ada menuntut aparatur untuk lebih aktif mencari informasi dan sumber pembelajaran agar peningkatan kualitas penyelenggaraan pelayanan dapat tetapterlaksana.

\section{SIMPULAN DAN REKOMENDASI}

\subsection{Simpulan}

Penyelenggaraan pelayanan pada DPMPTSP Kabupaten diukur berdasarkan 5 (lima) dimensi kualitas pelayanan publik, dapat dikatakan telah berhasil memenuhi hampir semua indikator pengukuran.

Berdasarkan analisis SWOT 
dihasilkan beberapa strategi yang sesuai dengan indikator strategi peningkatan kualitas pelayanan berdasarkan teori De Vreye. Strategistrategi tersebut menuntut komitmen, loyalitas, kreatifitas daninovasi dari aparatur pelaksana untuk dapat memanfaatkan semaksimal mungkin sarana prasarana yang ada guna menutupi kekurangan yang menjadi hambatan, seperti memanfaatkan media sosial, aplikasi, konten dan OSS dalam melakukan sosalisasi, koordinasi antar instansi, mencari literatur terkait pelayanan, dan merangkul masyarakat untuk berpartisipasi aktif guna meningkatkan kualitas pelayanan sehingga stigma negatif terkait pelayanan dapat dihilangkan. Strategi yang dapat direkomendasikan untuk meningkatkan kualitas pelayanan publik pada DPMPTSP Kabupaten Melawi yaitu "SERVICE" berkenaan dengan teori strategi peningkatan kualitas pelayanan yang dikemukakan De Vreye yaitu Self-esteem (harga diri/ kualitas diri), Exeed expectation (memenuhi harapan), Recovery (pembenahan), Vision (pandangan ke depan), Improve (perbaikan), Care (perhatian)

dan

Empower (pemberdayaan).

4.2. Rekomendasi

Penelitian mengenai strategi peningkatan kualitas pelayanan publik pada DPMPTSP Kabupaten Melawi menghasilkan rekomendasi kebijakan berupa implikasi manajerial yang diharap berguna bagi para pembaca khususnya instansi yang diteliti dan implikasi teoritis yang diharap member masukan dan manfaat bagi para pembaca penelitian ini khususnya kalanga akademisi yang akan melakukan penelitian dengan temaserupa.

\section{Referensi}

Alfisyahrin, M. (2018) . Peningkatan Kualitas Pelayanan Publik Di Indonesia. Jakarta : Yayasan Pustaka Obor Indonesia.

Gibson, J.L., Ivancevich, J.M dan Donnelly, J.H., (1996). Perilaku Organisasi, Struktur dan Proses. Terjemahan Djarkasih. Jakarta : Erlangga.

Hunger, J. D.,. (1996). Manajemen Strategis (Diterjemahkan oleh Julianto Agung). Yogyakarta: Penerbit ANDI Yogyakarta.

Hardiyansyah. (2018). Kualitas Pelayanan Publik (Edisi Revisi). Yogyakarta : Gava Media.

Lovelock, C.H \& Wright, L.K., 
(2005).Manajemen Pemasaran Jasa. Jakarta : PT. Indeks kelompok Gramedia.

Lovelock, C.H., (2011). Service Marketing : People, technology, Strategy. Pearson Education India.

Mulyadi, D.( 2018). Studi Kebijakan Publik dan Pelayanan Publik. Bandung: CV. Alfabeta.

Moenir., A.S., (2010). Manajemen Pelayanan Umum di Indonesia. Jakarta : Bumi Aksara.

Moleong, L. (2011). Metodologi Penelitian Kualitatif. Bandung : PT Remaja Rosdakarya.

Pamudji, S., (1994). Profesionalisme Aparatur Negara Dalam Meningkatkan Pelayanan Publik. Jakarta : IIP.

Rasyid, M.R., (2000). Makna Pemerintahan : Tinjauan dari Segi Etika dan Kepemimpinan. Jakarta Pusat : Mutiara Sumber Widya.

Ratminto dan Winarsih, AS., (2007). Manajemen Pelayanan Pengembangan Model Konseptual, Penerapan Citizen's Charter dan Standar PelayananMinimal. Yogyakarta : PustakaPelajar.

Peraturan Pemerintah :

Undang-Undang Nomor 25 Tahun 2009 tentang Pelayanan Publik.

Undang-Undang Nomor 34

Tahun 2003 tentang
Pembentukan Kabupaten

Melawi dan Kabupaten

Sekadau di Provinsi

Kalimantan Barat

Peraturan Menteri

Pemberdayaan Aparatur

Negara dan Reformasi

Birokrasi Republik

Indonesia Nomor 1 Tahun

2015 tentang Pedoman

Evaluasi Kinerja

Penyelenggraan

Pelayanan Publik

Peraturan Menteri Dalam

Negeri Nomor 20 tahun 2008 tentang Pedoman Organisasi dan Tata Kerja Unit Pelayanan Terpadu di Daerah. 